\title{
Seawater solubility of natural and anthropogenic metals within ambient aerosols collected from Taiwan coastal sites
}

\author{
Shih-Chieh Hsu ${ }^{\mathrm{a}, *}$, Fei-Jan Lin ${ }^{\mathrm{b}}$, Woei-Lih Jeng ${ }^{\mathrm{b}}$ \\ ${ }^{a}$ Research Center for Environmental Changes, Academia Sinica, Taipei, Taiwan, ROC \\ ${ }^{\mathrm{b}}$ Institute of Oceanography, National Taiwan University, Taipei, Taiwan, ROC
}

Received 10 November 2004; received in revised form 3 March 2005; accepted 12 March 2005

\begin{abstract}
To evaluate the bioavailability and environmental mobility of aerosol metals to the seas, ambient aerosol samples collected from two coastal sites, i.e., Hsiyu located at the southwestern tip of the Penghu Islands in Taiwan Strait and Santiaolun on the west coast of Taiwan were determined for the seawater solubility of $\mathrm{Al}, \mathrm{Fe}, \mathrm{Mn}, \mathrm{Zn}, \mathrm{Ni}, \mathrm{Cu}, \mathrm{Pb}$ and $\mathrm{Cd}$. The experiment of dissolution kinetics suggested that almost all soluble fractions of studied aerosol metals could be released within $1 \mathrm{~h}$. Thereafter, dissolved particle-reactive metals like $\mathrm{Al}, \mathrm{Fe}$ and $\mathrm{Pb}$ exhibited a slight decrease, suggestive of re-adsorption to residual particles. Seawater solubility of selected metals from Hsiyu aerosols showed the following order: $\mathrm{Al}(1.3 \%)=\mathrm{Fe}(1.1 \%)<\mathrm{Pb}(20 \%) \leqslant \mathrm{Cu}(27 \%)<\mathrm{Mn}(43 \%) \leqslant \mathrm{Zn}(45 \%) \leqslant \mathrm{Ni}(50 \%)<\mathrm{Cd}(69 \%)$. However, solubility data from Santiaolun were larger than those from Hsiyu for all aerosol metals analyzed, attributable to different degrees of anthropogenic contributions to the two sites. Moreover, $\mathrm{Pb}$ and $\mathrm{Ni}$ showed a positive correlation between solubility and $\log$ crustal enrichment factor $\left(\mathrm{EF}_{\text {crust }}\right)$, indicating that the dissolvable percentage is, to some extent, dependent on the anthropogenic contribution for specific aerosol metals and likely due to the presence of considerable contaminants such as organic, acidic and carbonaceous substances for anthropogenic aerosols. In addition, for $\mathrm{Al}, \mathrm{Fe}, \mathrm{Zn}$ and $\mathrm{Pb}$, inverse power-law $(\log -\log )$ correlations between solubilities and dust loadings have been observed, suggesting that particle scavenging may follow dissolution for certain metals in the marine environment. In conclusion, the dissolution of aerosol metals in seawater is predominantly controlled by which origins dominate their contributions (such as crustal or anthropogenic derivatives) and the behavior of a specific metal in seawater (such as dissolution/adsorption). Aerosol metals have substantial impacts on diverse eco-environments and accurate assessments of environmental impacts of eolian metal depositions must be based on such informative data. Thus more simulation experiments relevant to dissolution of aerosol metals in various natural waters are merited.
\end{abstract}

(C) 2005 Elsevier Ltd. All rights reserved.

Keywords: Dissolution; Enrichment factor; Dust loading; Eco-environment; Taiwan

\footnotetext{
*Corresponding author. Tel.: $886226539885 \times 252$; fax: 886227833584 .

E-mail address: schsu815@rcec.sinica.edu.tw (S.-C. Hsu).
}

\section{Introduction}

The dissolution of certain elements bound within aerosol particles in varying solution mediums including seawater and rainwater is crucial for biogeochemical issues with respect to public health (Voutsa and Samara, 2002), environmental mobility (Chester et al., 1994), 
aquatic contamination (Davison et al., 1994), bioavailability (Avila and Rodrigo, 2004; Kersten et al., 1991), marine biogeochemistry (Duce et al., 1991; Guerzoni et al., 1999a; Jickells, 1999) and cloud processes as well (Spokes et al., 1994; Wise et al., 2003). Indeed, a number of the first-row transition metals are suggested as being essential for marine organisms (Bruland et al., 1991; Coale, 1991; Butler, 1998; Sunda and Huntsman, 1998). More importantly, recent studies have demonstrated that eolian dissolvable $\mathrm{Fe}$ as well as $\mathrm{Zn}$ contributed from long-range transport can stimulate marine production that is closely related to atmospheric $\mathrm{CO}_{2}$ concentrations and thus also to climate change (Martin and Fitzwater, 1988; Coale et al., 1996; Cooper et al., 1996; Schulz et al., 2004). This relationship has also been confirmed by studies of the paleoclimate from sediment and ice cores and by a series of in situ Fe-fertilizing experiments (Martin et al., 1994; Kumar et al., 1995; Petit et al., 1999; Boyd et al., 2000; Bopp et al., 2003). Further evidence confirms not all eolian Fe but dissolved fractions or specific speciation are available for phytoplankton growth (Hutchins et al., 1999; Barbeau and Moffett, 2000). In contrast to naturally derived compositions, extra contributions from numerous anthropogenic, toxic metals through dissolution of deposited aerosol particles may disturb the original cycles and budget balance in the seas and are thus detrimental to marine organisms (de Vries et al., 1998; Van den Hout et al., 1999). For example, the southern East China Sea off northern Taiwan was found to have the largest surface dissolved $\mathrm{Pb}$ concentration ever documented in marginal seas and open oceans over the world, attributable to long-range transported atmospheric $\mathrm{Pb}$ deposition from the Chinese mainland (Lin et al., 2000).

The problem of which amounts of natural and anthropogenic metals bound within aerosol particles are deposited in diverse environments is of concern, while the question of which proportion is labile to really interact with the ecosystems and which is refractory (inert, and thus likely to be stable in environments) must be clarified (Duce et al., 1991). Therefore, a better understanding of dissolution behaviors and dissolvable proportions of aerosol metals will facilitate the precise estimation and risk assessment for atmospheric depositions of selected metals with a nutrient (or nutrient-like) nature and toxicity to organisms and plants and has now become urgent. The solubility of aerosol metals in various aqueous media like seawater, rainwater, cloudwater, and fresh water can be affected by a number of controlling factors such as solution $\mathrm{pH}$ (Statham and Chester, 1988; Lim et al., 1994; Chester et al., 1997, 2000; Desboeufs et al., 1999), crustal enrichment factor $\left(\mathrm{EF}_{\text {crust }}\right)$ value of certain metals (Chester et al., 1993; Guerzoni et al., 1999b), particle loading in solution (Guerzoni et al., 1999b), aerosol type and size (Davison et al., 1994; Chester et al., 1993, 1994, 1997), photo- reduction (Zhuang et al., 1992; Zhu et al., 1993) and the presence of organic, acidic or carbonaceous substances (Zuo, 1995; Desboeufs et al., 2001, 2005). Their relative importance is variable, depending on which solutions interact with aerosols, which compositions dominate aerosols, and which specific metals are of interest. So far the literature data on seawater solubility of aerosol metals are limited, and almost all such data are for the Atlantic Ocean and Mediterranean Sea (Statham and Chester, 1988; Kersten et al., 1991; Chester et al., 1993; Guieu et al., 1994; Bonnet and Guieu, 2004); in contrast, little data have been reported for the Pacific Ocean (Zhuang et al., 1992), and particularly for East Asia, which is becoming a sensitive area regarding air pollution and dust outflow. More importantly, some inconsistencies or reference to wide ranges of seawater solubilities for specific aerosol metals exist in previous studies, especially for $\mathrm{Fe}$ (Hand et al., 2004; and references therein), and this makes the comparison and utilization of such datasets more difficult.

Marine aerosol samples collected from two sites, an offshore island site (Hsiyu) of the Penghu Islands in the Taiwan Strait (characterized by less anthropogenic impact) and a coastal site (Santiaolun) in western Taiwan near an industrial area, were processed by a series of dissolution experiments and analyzed for a suite of natural and anthropogenic metals including $\mathrm{Al}, \mathrm{Fe}$, $\mathrm{Mn}, \mathrm{Ni}, \mathrm{Cu}, \mathrm{Zn}, \mathrm{Pb}$ and $\mathrm{Cd}$. The purposes of this study were to establish the dissolution kinetics of specific aerosol metals in seawater, to quantify seawater solubilities of specific aerosol metals, and to examine the controlling factors of dissolution of selected aerosol metals. In addition, the limited amount of seawater solubility data for aerosol metals is, to some extent, owing to the analytical difficulties such as interference by the sea salt matrix of seawater and low levels of leached metal concentrations in seawater. In the study, we successfully employed an alternative method to determine the seawater solubility indirectly.

\section{Materials and method}

\subsection{Sampling}

Marine aerosol samples were collected from a small volcanic island, Hsiyu of the Penghu Islands in the Taiwan Strait (Fig. 1), over the period February 1991-January 1992. For comparison, aerosol samples were also collected from a coastal site, Santiaolun in western Taiwan neighboring the Taiwan Strait (Fig. 1), in early 1992. The prevailing northeast monsoon winds carry massive quantities of Asian dust and pollutants from mainland China to Taiwan in winter and spring (November-May), and frequent rain, that causes effective removal processes for atmospheric particles, and 


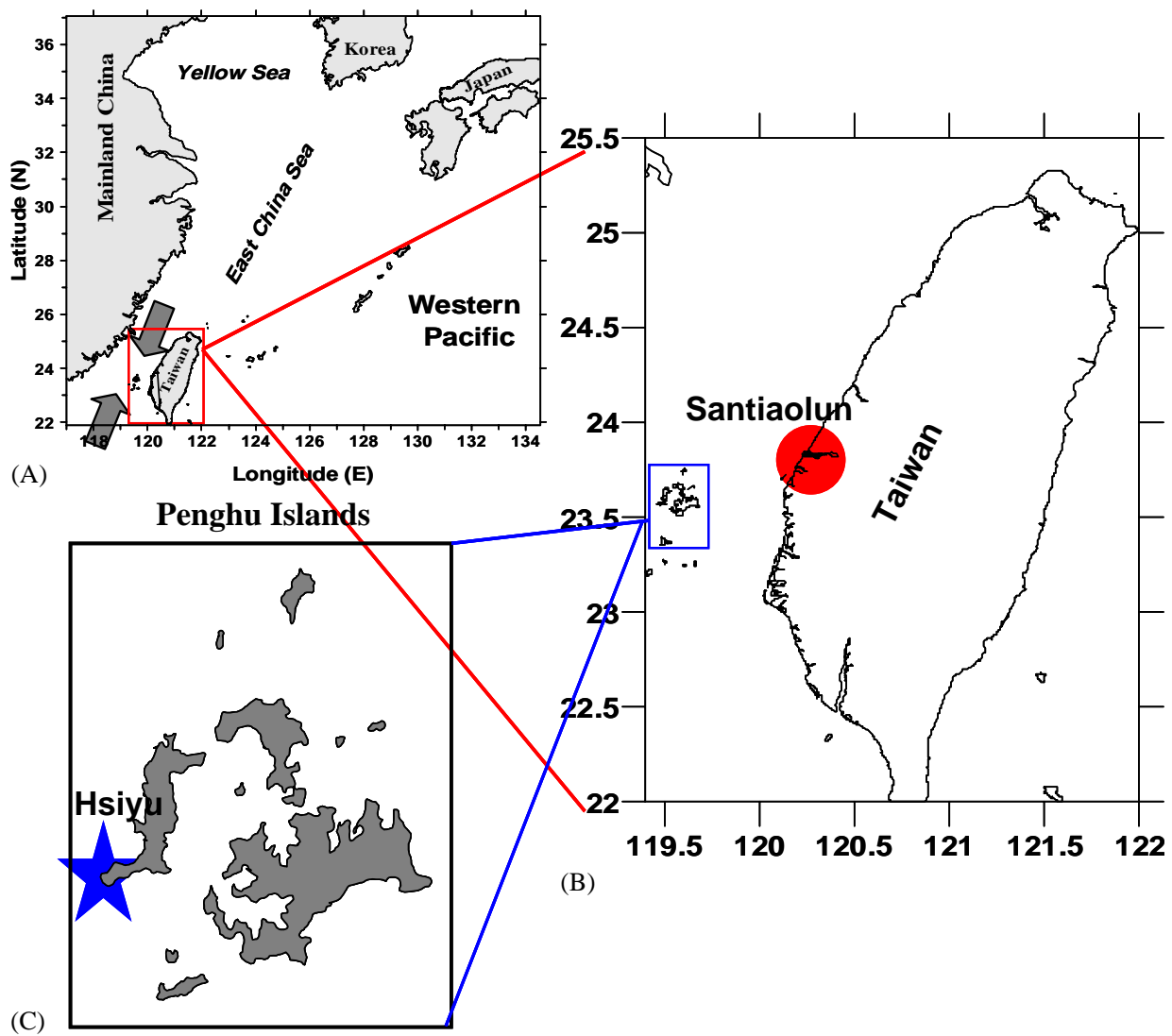

Fig. 1. Sampling location map, including (A) regional map, (B) Taiwan and (C) Penghu Islands in the Taiwan Strait for two sites, Santiaolun (filled circle) in western Taiwan and Hsiyu (filled star) of the Penghu Islands. Arrows in plot (A) indicate the prevailing winds in winter (arrow pointing south) and summer (arrow pointing north).

cessation of intercontinental transport in summer (the rest of the year) usually result in a typical seasonality for numerous dust-derived and anthropogenic metals (e.g. $\mathrm{Pb}$ and $\mathrm{Cd}$ ) in northern Taiwan, thus displaying high winter/spring and low summer concentrations (Hsu et al., 2004, 2005). Air pollutants over the Penghu Islands originate dominantly from long-range transport. The air here is relatively free from local pollution since heavy industries are scarce (Yuan et al., 2004). The same situation as that in northern Taiwan may be encountered at the Hsiyu site. In contrast, the Santiaolun site suffers from local pollution since there are fossil-fuel related industries. The island site is $200 \mathrm{~m}$, and the coastal site $500 \mathrm{~m}$ away from the sea. High volume aerosol samplers (motor model GBM2000H; Andersen Instruments, USA) were set up on the rooftop of residential buildings approximately $10 \mathrm{~m}$ above ground level for collecting ambient total suspended particles (TSP). The view from sampling sites to the sea was unimpeded. Continuous sampling was conducted regardless of weather conditions. Collection time periods for each aerosol sample varied from 2 to 3 days for the Hsiyu station and were 2 days for the Santiaolun station. Flow rates were recorded with a continuous flow recorder. Whatman ${ }^{\mathbb{R}} 41$ cellulose filters $\left(8^{\prime \prime} \times 10^{\prime \prime}\right)$ (Whatman Limited, Maidstone, UK), acid-cleaned and conditioned in a desiccator, were employed for filtration. Samplers were operated at a rate of $\sim 60 \mathrm{~m}^{3} \mathrm{~h}^{-1}$. Air volumes filtered for each sample were integrated for the whole sampling period. Each sheet of post-collected paper filter was equally folded and placed into an individual PE bag followed by storage at temperatures of $\sim 22^{\circ} \mathrm{C}$ and relative humidity of $\sim 35 \%$ in a desiccator until later analysis.

\subsection{Dissolution experiment and chemical analysis}

A total of 36 samples (28 from Hsiyu and 8 from Santiaolun) were collected for the dissolution study; two of these (\#H0221 and \#S0104, see Tables 1 and 2) were chosen for studying dissolution kinetics first. These TSPladen filters were cut into quarters using ceramic scissors on a class-100 laminar flow bench, with the exception of the two samples chosen for the kinetic experiment which were cut into eight equal pieces. One-quarter of each 
Table 1

Results of accuracy and precision $(n=10)$ of analyzing standard reference materials (SRM 1648, urban atmospheric particulate)

\begin{tabular}{lcccc}
\hline Element & Certified value & This work & Accuracy (\%) & Precision (\%) \\
\hline $\mathrm{Al}$ & $3.42 \pm 0.11 \%$ & $3.39 \pm 0.07 \%$ & 99 & 1.9 \\
$\mathrm{Fe}$ & $3.91 \pm 0.1 \%$ & $3.88 \pm 0.03 \%$ & 99 & 0.9 \\
$\mathrm{Zn}$ & $0.476 \pm 0.014 \%$ & $0.467 \pm 0.007 \%$ & 98 & 1.4 \\
$\mathrm{~Pb}$ & $0.655 \pm 0.008 \%$ & $0.635 \pm 0.006 \%$ & 97 & 1.0 \\
$\mathrm{Mn}$ & $860 \mathrm{mg} \mathrm{kg}^{-1 \mathrm{a}}$ & $776 \pm 9 \mathrm{mg} \mathrm{kg}^{-1}$ & 90 & 1.1 \\
$\mathrm{Cu}$ & $609 \pm 27 \mathrm{mg} \mathrm{kg}^{-1}$ & $569 \pm 24 \mathrm{mg} \mathrm{kg}^{-1}$ & 93 & 4.2 \\
$\mathrm{Ni}$ & $82 \pm 3 \mathrm{mg} \mathrm{kg}^{-1}$ & $86 \pm 6 \mathrm{~m} \mathrm{~kg}^{-1}$ & 104 & 7.1 \\
$\mathrm{Cd}$ & $75 \pm 7 \mathrm{mg} \mathrm{kg}^{-1}$ & $77 \pm 2 \mathrm{~m} \mathrm{~kg} \mathrm{~g}^{-1}$ & 103 & 2.9 \\
\hline
\end{tabular}

${ }^{\mathrm{a}}$ Non-certified value.

filter cut into quarters was used for the dissolution experiment and another for bulk sample analysis by total digestion. In addition, seawater used for the dissolution experiment was taken from the Taiwan Strait on cruise OR310 (February 1992) and immediately subjected to in situ filtration. Back in the landbased laboratory, seawater was irradiated by ultraviolet light (power $1000 \mathrm{~W}$ ) to break down dissolved organics and then purified through ion-exchange resin columns (Chelex-100) to minimize the content of dissolved metal impurities (approx. $1 \mu \mathrm{gl}^{-1}$ for $\mathrm{Al}, \mathrm{Mn}, \mathrm{Ni}, \mathrm{Cu}, \mathrm{Zn}$ and $\mathrm{Pb}, 0.1 \mu \mathrm{gl}^{-1}$ for $\mathrm{Fe}$, and $0.01 \mu \mathrm{g} \mathrm{l^{-1 }}$ for $\mathrm{Cd}$ ) at least more than one to two orders of magnitude lower than those in the extracted solutions. For the details for seawater sampling and treatments, refer to $\mathrm{Hsu}$ et al. (2003a, b).

In the case of the kinetic experiment, a total of sixeighths of the sample-containing filters were individually placed into $100 \mathrm{ml}$ wide-mouth polypropylene bottles (Nalgene) with $50 \mathrm{ml}$ pretreated seawater $(\mathrm{pH}=8.3)$ and then reciprocally shaken for several time periods $(0.5,1,3,6,12$ and $24 \mathrm{~h})$. When each dissolution time was completed, seawater extracts together with aerosolcontaining filters were individually filtered through an acid-precleaned polycarbonate membrane filter $(47 \mathrm{~mm}$ in size with pore size $0.4 \mu \mathrm{m}$, Nuclepore). To eliminate the likely interference of sea salt in chemical analysis, $100 \mathrm{ml}$ distilled deionized water (DDW) was passed through the filter to remove residual seawater after filtration. We believe that the occurrence of additional metal release during the filtration is insignificant based on two facts: (1) prior to the procedure most extractable fractions of metals of interest have been released in the dissolution experiment, as shown below, and (2) undetectable trace metals were found in the rinsing DDW. The residual filters (including cellulose and polycarbonate) were subsequently subjected to acid digestion for analysis of the insoluble fraction rather than directly analyzing the dissolved fraction in seawater in order to avoid interference in metal measurements. Another eighth of the filter of each of the two selected samples was independently processed by total digestion, for which the general procedures are given below. Accordingly, the seawater solubility of a given metal can be calculated by the following equation:

Solubility
$=\frac{\text { total concentration }- \text { insoluble concentration }}{\text { total concentration }} \times 100 \%$.

The optimal leaching time was determined to be $1 \mathrm{~h}$ based on the dissolution kinetics of metals of interest (Fig. 2), as described in Section 3, and was hence adopted in the subsequent dissolution experiments for other samples. For all other selected sample filters, a quarter was processed by the above-mentioned procedures for seawater dissolution, while another quarter was used for total digestion.

For acid digestion, particulate-laden filters were dissolved in an acid mixture of $10 \mathrm{ml} 69 \% \mathrm{HNO}_{3}, 5 \mathrm{ml}$ $60 \% \mathrm{HF}$ and $0.5 \mathrm{ml} \mathrm{70 \%} \mathrm{HClO}_{4}$ (Suprapur grade from Merck) in PTFE beakers and heated on a hot plate at $\sim 200^{\circ} \mathrm{C}$ until complete dissolution. The digestion solution was dried, and the residue was then redissolved in $2 \mathrm{ml} 69 \% \mathrm{HNO}_{3}$ and ultimately diluted with DDW to $20 \mathrm{ml}$ (in $2 \% \mathrm{HNO}_{3}$ ). The digestion method is similar to that of Hsu et al. (2004). Digested solutions were stored in a refrigerator at $4{ }^{\circ} \mathrm{C}$ for later analysis. All containers used were acid-cleaned prior to use. Metal analysis was made with a Hitachi Z-8100 flameless atomic absorption spectrophotometer (graphite furnace) equipped with a Zeeman correction system. Metal concentrations were quantified by calibrations against working standards prepared from Merck stock standard. A total of six blanks were prepared in the same manner as the samples to ensure experimental quality. Quality assurance and quality control (QA/QC) of data and methods were validated by the measurement of standard reference material NIST-SRM1648 (urban particulate) under total digestion treatment. Accuracy and precision 
Table 2

Overall data $(n=28)$ on seawater solubility ( $\%$ ) of various aerosol metals from all Hsiyu samples. Also included is dust loading on each filter (mg per filter), which can be converted to dust concentration in $\mathrm{mg}^{-1}$ by multiplying by 2.5 (see text). Samples were simply separated into two groups, namely a high loading group with dust loading higher than $50 \mathrm{mg}$ per filter and a low loading group with dust loading lower than $50 \mathrm{mg}$ per filter

\begin{tabular}{|c|c|c|c|c|c|c|c|c|c|}
\hline Sample ID & $\mathrm{Al}$ & $\mathrm{Fe}$ & $\mathrm{Mn}$ & $\mathrm{Zn}$ & $\mathrm{Ni}$ & $\mathrm{Cu}$ & $\mathrm{Pb}$ & $\mathrm{Cd}$ & Dust loading (mg per filter) \\
\hline H910224 & $0.02 \pm 0.3\left(1^{\mathrm{a}}\right)$ & $0.1 \pm 0.6(1.0)$ & $35 \pm 1(1.6)$ & $33 \pm 1(8)$ & $32 \pm 2(6)$ & $24 \pm 2(5)$ & $6 \pm 1(8)$ & $77 \pm 1(3)$ & 189 \\
\hline H910227 & $1.5 \pm 1.6(1)$ & $2.0 \pm 1.3(1.0)$ & $61 \pm 1(1.5)$ & $74 \pm 1(75)$ & $61 \pm 2(16)$ & $23 \pm 3(61)$ & $35 \pm 1(94)$ & $86 \pm 0(120)$ & 52 \\
\hline H910305 & $3.2 \pm 3.1(1)$ & $1.0 \pm 2.7(1.1)$ & $58 \pm 1(1.2)$ & $68 \pm 1(185)$ & $72 \pm 1(28)$ & $27 \pm 4(113)$ & $31 \pm 2(128)$ & $20 \pm 3(226)$ & 26 \\
\hline H910317 & $1.2 \pm 1.2(1)$ & $0.4 \pm 0.9$ & $51 \pm 1(1.4)$ & $59 \pm 1(23)$ & $51 \pm 3(10)$ & $32 \pm 2(22)$ & $22 \pm 1(57)$ & $80 \pm 0(101)$ & 70 \\
\hline H910323 & $0.8 \pm 2.3(1)$ & $0.6 \pm 1.8(1.1)$ & $50 \pm 1(1.2)$ & $77 \pm 1(76)$ & $69 \pm 1(19)$ & $25 \pm 3(63)$ & $35 \pm 2(117)$ & $81 \pm 1(98)$ & 43 \\
\hline H910408 & $2.5 \pm 2.8(1)$ & $1.4 \pm 3.3(1.1)$ & $66 \pm 1(2.3)$ & $71 \pm 1(75)$ & $72 \pm 2(45)$ & $40 \pm 4(110)$ & $35 \pm 2(229)$ & $83 \pm 1(341)$ & 27 \\
\hline H910423 & $1.5 \pm 3.0(1)$ & $1.8 \pm 2.7(1.0)$ & $58 \pm 1(1.3)$ & $75 \pm 1(45)$ & $43 \pm 3(9)$ & $27 \pm 3(52)$ & $39 \pm 1(123)$ & $88 \pm 0$ & 53 \\
\hline H910601 & $0.1 \pm 0.6(1)$ & $0.1 \pm 0.2(1.7)$ & $9 \pm 1(1.9)$ & $11 \pm 1(35)$ & $3 \pm 5$ & $15 \pm 3(18)$ & $1 \pm 1(46)$ & $58 \pm 0(27)$ & 76 \\
\hline H910610 & $0.1 \pm 0.5(1)$ & $0.04 \pm 0.8$ & $9 \pm 2(1.9)$ & $5 \pm 1(25)$ & $1 \pm 3(4)$ & $17 \pm 2(14)$ & $3 \pm 1(70)$ & $39 \pm 1(76)$ & 79 \\
\hline H910616 & $0.3 \pm 1.5(1)$ & $0.1 \pm 0.9$ & $10 \pm 2(1.6)$ & $18 \pm 2(59)$ & $21 \pm 4(2)$ & $10 \pm 4(28)$ & $6 \pm 1(125)$ & $51 \pm 1(71)$ & 36 \\
\hline H910625 & $1.2 \pm 3.7(1)$ & $1.4 \pm 3.2(1.1)$ & $49 \pm 2(1.6)$ & $60 \pm 2(69)$ & $60 \pm 2(22)$ & $16 \pm 4(96)$ & $17 \pm 3(103)$ & $81 \pm 1(123)$ & 24 \\
\hline H910704 & $0.4 \pm 1.5(1)$ & $0.3 \pm 1.5(2.1)$ & $4 \pm 2(2.3)$ & $1 \pm 2(25)$ & $4 \pm 5(3)$ & $11 \pm 4$ & $6 \pm 2(69)$ & $40 \pm 1(48)$ & 49 \\
\hline H910710 & $1.0 \pm 3.0(1)$ & $0.2 \pm 1.4(1.2)$ & $16 \pm 2(1.5)$ & $14 \pm 3(19)$ & $1 \pm 4(3)$ & $9 \pm 4(55)$ & $1 \pm 3(58)$ & $44 \pm 2(26)$ & 35 \\
\hline H910723 & $0.3 \pm 1.5$ & $0.6 \pm 1.2(0.9)$ & $9 \pm 1(1.4)$ & $5 \pm 2(22)$ & $68 \pm 2(4)$ & $39 \pm 3(43)$ & $2 \pm 1$ & $69 \pm 1(38)$ & 87 \\
\hline H910801 & $0.8 \pm 2.9(1)$ & $0.7 \pm 2.3(1.2)$ & $20 \pm 2(1.7)$ & $21 \pm 2(24)$ & $41 \pm 3(4)$ & $22 \pm 3(59)$ & $22 \pm 2(111)$ & $44 \pm 2(51)$ & 28 \\
\hline H910807 & $0.1 \pm 0.6(1)$ & $0.2 \pm 0.4(0.6)$ & $10 \pm 1(0.8)$ & $5 \pm 1(8)$ & $21 \pm 4(2)$ & $16 \pm 3(18)$ & $2 \pm 1(20)$ & $50 \pm 0(5)$ & 114 \\
\hline H910814 & $0.7 \pm 2.5$ & $0.3 \pm 1.4(1.2)$ & $30 \pm 2(1.5)$ & $28 \pm 2(25)$ & $34 \pm 3(6)$ & $30 \pm 3(51)$ & $9 \pm 3(58)$ & $79 \pm 1(57)$ & 53 \\
\hline H910823 & $0.1 \pm 0.5(1)$ & $0.2 \pm 0.1$ & $28 \pm 0(1.3)$ & $35 \pm 0(23)$ & $33 \pm 3(4)$ & $18 \pm 3(28)$ & $11 \pm 0$ & $87 \pm 0(88)$ & 93 \\
\hline H910902 & $1.0 \pm 2.3(1)$ & $1.4 \pm 2.0(1.3)$ & $53 \pm 1(1.9)$ & $61 \pm 1(51)$ & $48 \pm 2(8)$ & $21 \pm 3(47)$ & $23 \pm 2(126)$ & $84 \pm 0(871)$ & 49 \\
\hline H911018 & $0.5 \pm 0.8$ & $0.2 \pm 0.1$ & $28 \pm 1(1.4)$ & $24 \pm 0(10)$ & $8 \pm 4(6)$ & $16 \pm 3(8)$ & $3 \pm 2(30)$ & $72 \pm 1(14)$ & 98 \\
\hline H911022 & $2.2 \pm 1.5(1)$ & $0.9 \pm 1.2$ & $60 \pm 1(1.4)$ & $60 \pm 1(23)$ & $78 \pm 1(27)$ & $45 \pm 2(19)$ & $24 \pm 1(76)$ & $86 \pm 0(68)$ & 35 \\
\hline H911114 & $0.6 \pm 2.0$ & $0.5 \pm 1.4(2.0)$ & $68 \pm 1(2.7)$ & $65 \pm 1(32)$ & $79 \pm 1(86)$ & $28 \pm 4(19)$ & $33 \pm 1\left(\begin{array}{lll}1 & 0 & 1\end{array}\right)$ & $87 \pm 0(143)$ & 20 \\
\hline H911225 & $0.7 \pm 1.8$ & $1.7 \pm 1.7(1.5)$ & $64 \pm 1(1.8)$ & $61 \pm 1(43)$ & $82 \pm 1(64)$ & $40 \pm 2(23)$ & $24 \pm 2(88)$ & $77 \pm 1(81)$ & 27 \\
\hline H911228 & $0.7 \pm 1.9(1)$ & $3.8 \pm 1.3(1.5)$ & $74 \pm 1(3.3)$ & $66 \pm 1(50)$ & $85 \pm 1(113)$ & $37 \pm 2(22)$ & $29 \pm 1(173)$ & $44 \pm 1\left(\begin{array}{lll}1 & 1 & 1\end{array}\right)$ & 23 \\
\hline H911230 & $6.9 \pm 4.4(1)$ & $2.8 \pm 3.8(2.4)$ & $74 \pm 1(5.4)$ & $72 \pm 2(172)$ & $85 \pm 1(203)$ & $40 \pm 4(98)$ & $31 \pm 3(668)$ & $67 \pm 2(639)$ & 6 \\
\hline H920106 & $4.7 \pm 3.8$ & $2.6 \pm 3.7(1.9)$ & $72 \pm 1(3.5)$ & $66 \pm 1(63)$ & $83 \pm 1(124)$ & $32 \pm 4(28)$ & $29 \pm 3(239)$ & $91 \pm 0(413)$ & 13 \\
\hline H920116 & $0.4 \pm 1.3(1)$ & $1.0 \pm 2.0$ & $61 \pm 1(2.0)$ & $59 \pm 1(36)$ & $78 \pm 1$ & $34 \pm 1(9)$ & $32 \pm 1(134)$ & $85 \pm 0(94)$ & 61 \\
\hline H920123 & $2.9 \pm 1.6(1)$ & $5.6 \pm 1.3(1.4)$ & $70 \pm 1(3.0)$ & $69 \pm 1(74)$ & $86 \pm 1(83)$ & $48 \pm 2(17)$ & $45 \pm 1(331)$ & $89 \pm 0(253)$ & 36 \\
\hline \multicolumn{10}{|l|}{ Average } \\
\hline Total & $1.3 \pm 1.2$ & $1.1 \pm 1.2$ & $43 \pm 1$ & $45 \pm 1$ & $50 \pm 1$ & $27 \pm 1$ & $20 \pm 1$ & $69 \pm 1$ & 43 \\
\hline H-loading & $0.5 \pm 1.3$ & $0.6 \pm 1.3$ & $32 \pm 1$ & $34 \pm 1$ & $36 \pm 1$ & $24 \pm 1$ & $14 \pm 1$ & $73 \pm 1$ & \\
\hline L-loading & $1.9 \pm 1.3$ & $1.6 \pm 1.3$ & $51 \pm 1$ & $53 \pm 1$ & $60 \pm 1$ & $28 \pm 1$ & $24 \pm 1$ & $67 \pm 1$ & \\
\hline $\mathrm{L} / \mathrm{H}$ ratio $^{\mathrm{b}}$ & 3.4 & 2.7 & 1.6 & $1 . \overline{5}$ & $1 . \overline{7}$ & 1.2 & 1.8 & 0.9 & \\
\hline
\end{tabular}

${ }^{a}$ Numbers in parentheses are crustal enrichment factors.

${ }^{\mathrm{b}} \mathrm{The} \mathrm{L} / \mathrm{H}$ is the ratio of average solubility of certain metals for the low loading group to that for the high loading group. 

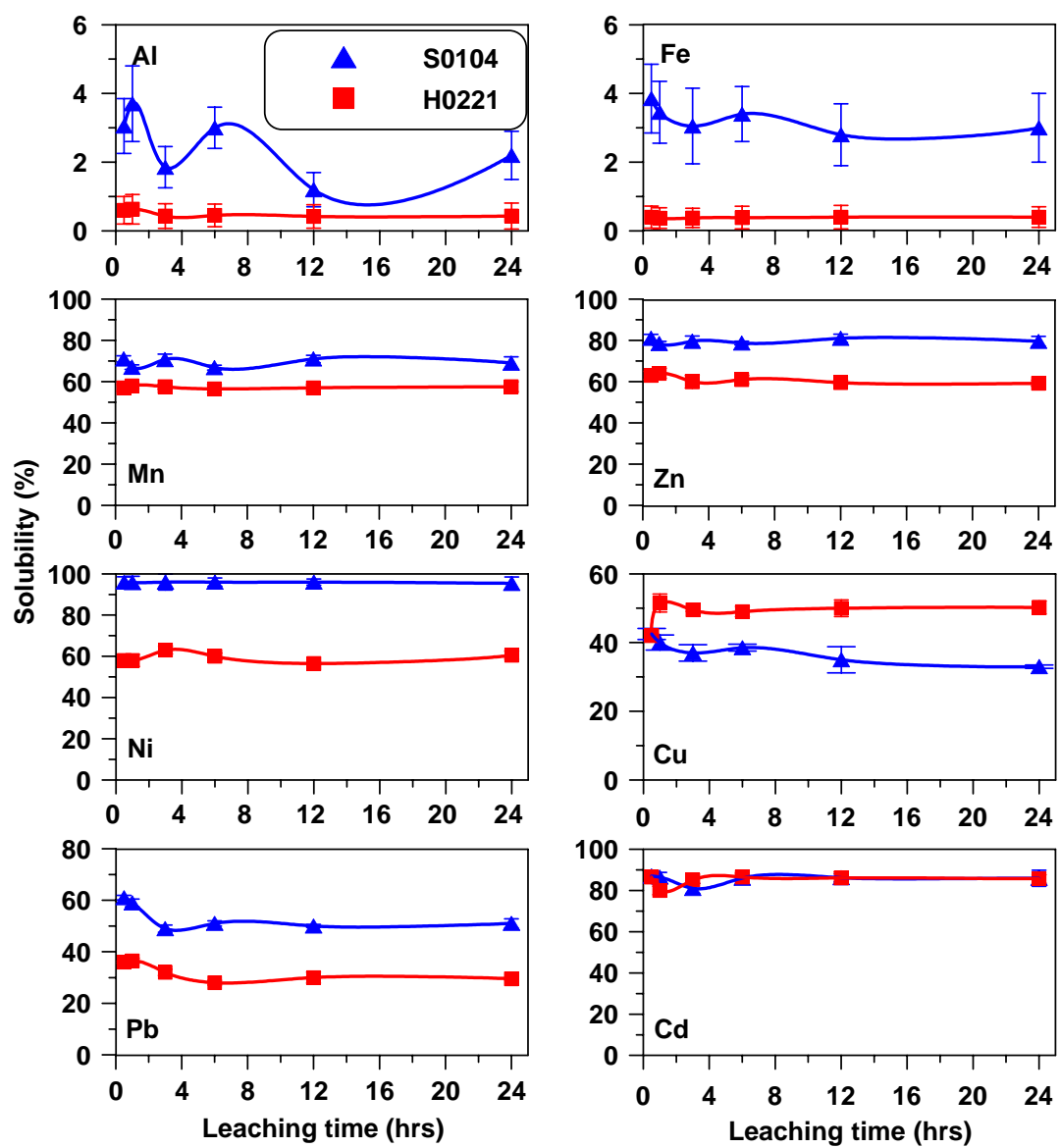

Fig. 2. Dissolution kinetics for selected metals (Al, Fe, Mn, $\mathrm{Zn}, \mathrm{Ni}, \mathrm{Cu}, \mathrm{Pb}$ and $\mathrm{Cd}$ ) in two aerosol samples, one from $\mathrm{Hsiyu}$ (sample ID \#H0221) and the other from Santiaolun (sample ID \#S0104). Error bars indicate the uncertainty of sample handling, analysis as well as the inhomogeneity of six-eighths of each aerosol-laden filter.

$(n=10)$ for all selected metals were within a few percent of certified (or non-certified for Mn) values (Table 1), satisfying the QA/QC requirement. Details of chemical analysis have been published elsewhere (Lin et al., 2000; Hsu et al., 2003a, b). Moreover, a uniformity test was carried out by measuring metal concentrations of the four quarters of an aerosol-embedded filter; the mean variability of less than $3 \%$ was obtained $(1.1 \%$ for $\mathrm{Al}$, $0.3 \%$ for $\mathrm{Fe}, 1.1 \%$ for $\mathrm{Mn}, 3 \%$ for $\mathrm{Cd}, 2.7 \%$ for $\mathrm{Cu}$, $0.7 \%$ for $\mathrm{Pb}, 2.1 \%$ for $\mathrm{Zn}$, and $1.9 \%$ for $\mathrm{Ni}$ ), meeting the experimental demands.

\subsection{Methods}

To evaluate the anomaly of specific chemical species of ambient aerosols relative to representative compositions of a reference material (e.g., average crust and sea water), an enrichment factor (EF) is defined and the following equation is used for calculation (e.g. Chester et al., 1993; Hsu et al., 2004, 2005):

$\mathrm{EF}_{\text {crust }}=(\mathrm{M} / \mathrm{Al})_{\text {aerosol }} /(\mathrm{M} / \mathrm{Al})_{\text {crust }}$,

where $(\mathrm{M} / \mathrm{Al})_{\text {aerosol }}$ is the concentration ratio of a given metal $\mathrm{M}$ to $\mathrm{Al}$ in aerosols, and $(\mathrm{M} / \mathrm{Al})_{\text {crust }}$ is the concentration ratio of a given metal $\mathrm{M}$ to $\mathrm{Al}$ in crust (Taylor, 1964). $\mathrm{EF}_{\text {crust }}$ values were used to examine the correlation with the seawater solubility for each studied metal, but they should only be treated as order of magnitude indicators (Kersten et al., 1991), as discussed below. In addition, dust loading, another parameter considered for governing the solubility of aerosol metals in seawater, can be calculated by the following equation:

Dust loading $=C_{\mathrm{Al}} \times V_{\text {air }} / 8 \% / 0.05$,

where $C_{\mathrm{Al}}$ is $\mathrm{Al}$ atmospheric concentration, $V_{\text {air }}$ the filtered air volume for each sample, $8 \%$ the $\mathrm{Al}$ abundance in average crust, and 0.051 the leaching seawater volume. 


\section{Results and discussion}

\subsection{Dissolution kinetics of aerosol metals in seawater}

The dissolution kinetics of selected aerosol metals in seawater is displayed by plotting solubility against leaching time spanning from half an hour to $24 \mathrm{~h}$, as shown in Fig. 2. The error bars plotted in Fig. 2 are comprehensive uncertainties that arose from sample handling, analysis and inhomogeneity, and propagation of errors through calculations. Aluminum reached a maximal solubility at $1 \mathrm{~h}$ (nearly $4 \%$ for sample S0104 and about $1 \%$ for sample H0221), thereafter declined slightly, and maintained at pseudo-equilibrium with a quasi-constant solubility (less than $3 \%$ and $1 \%$, respectively). The solubility of $\mathrm{Fe}$ is quite similar to that of $\mathrm{Al}$, but its solubility reached a maximum at $0.5 \mathrm{~h}$. Solubility for $\mathrm{Pb}$ reached a maximum at 0.5 and $1 \mathrm{~h}$ for the two samples, respectively $(60 \%$ for S0104 and $35 \%$ for $\mathrm{H} 0221$ ), thereafter tended to decrease, and after $6 \mathrm{~h}$ maintained at rather quasi-constant percentages $(50 \%$ and $30 \%$ ); its kinetic pattern is like those of $\mathrm{Al}$ and Fe. In the cases of $\mathrm{Mn}, \mathrm{Zn}, \mathrm{Ni}$ and $\mathrm{Cd}$, a common kinetic pattern was shared, i.e. rapidly reaching a maximum before $1 \mathrm{~h}$ and thereafter maintaining at their individual quasi-constant solubilities. Note that the quasi-constant solubilities are not identical among elements and between the two samples. For $\mathrm{Cu}$, kinetics are somewhat different between the two samples, showing that one ( $\mathrm{S} 0104)$ is similar to $\mathrm{Pb}$ with a low decreasing tendency after reaching a maximum at half an hour, and the other (H0221) is like $\mathrm{Mn}, \mathrm{Zn}, \mathrm{Ni}$ and $\mathrm{Cd}$, revealing a quasiconstant dissolution after reaching a maximum within $1 \mathrm{~h}$. Nonetheless, Desboeufs et al. (2005) addressed the issue, explaining that the dissolution kinetics of aerosol metals is not constant but a function of time. Moreover, according to earlier studies (Zhuang et al., 1992; Bonnet and Guieu, 2004; Desboeufs et al., 2005), the time for reaching the maximal or quasi-constant solubility for aerosol metals was a few minutes only (shorter than ours), but a shorter time may lead to a loss of some information on the dissolution behavior of specific aerosol metals. Desboeufs et al. (2005) calculated the dissolution rates and found that they are very rapid in the first $20 \mathrm{~min}$ of leaching and tend to be stable at lower values as compared to initial rates.

In summary, the dissolution behavior of specific metals may essentially depend on the nature of elements in seawater as well as the characteristic of their origins (e.g. anthropogenic versus natural). For those particlereactive metals such as $\mathrm{Al}, \mathrm{Fe}$ and $\mathrm{Pb}$, labile fractions appear to be rapidly released from aerosol particles while dissolving in seawater, but a minor fraction of dissolved metals may immediately be subjected to readsorption to residual particles (Kersten et al., 1991; Davison et al., 1994), reaching a pseudo-equilibrium between dissolved and residual particulate metals. With essentially anthropogenic origins, $\mathrm{Zn}, \mathrm{Cd}, \mathrm{Cu}$, and $\mathrm{Ni}$, elucidated by high $\mathrm{EF}_{\text {crust }}$ values (Table 2) can easily maintain at quasi-constant maximal solubility and usually have higher solubility compared to the particlereactive elements $(\mathrm{Al}, \mathrm{Fe}$ and $\mathrm{Pb})$ and/or crust-derived elements ( $\mathrm{Al}$ and $\mathrm{Fe})$. It is noted that there are different kinetic patterns between $\mathrm{Mn}$ and $\mathrm{Fe}$ although their EFcrust values are close $\left(\mathrm{EF}_{\mathrm{Fe}}=0.8\right.$ and $\mathrm{EF}_{\mathrm{Mn}}=1.3$ for sample $\mathrm{H} 0211$, and $\mathrm{EF}_{\mathrm{Fe}}=1.0$ and $\mathrm{EF}_{\mathrm{Mn}}=3.8$ for sample S0104), similar to those of Spokes et al. (1994). Apart from their different sources (the mixed crust and anthropogenic sources for $\mathrm{Mn}$ and the exclusively crustal source for Fe), they suggested that the chemical associations are essentially responsible for the difference in dissolution patterns of $\mathrm{Mn}$ and $\mathrm{Fe}$, dominated by the loose bound, oxide and carbonate phases for Mn and by the refractory, crystalline aluminosilicate phase for Fe. In addition to the above-mentioned factors, chemical interactions between a fraction of dissolved metals with dissolved organic ligands in seawater that likely come from incomplete breakdown of originally existing organic ligands prior to dissolution experiment and/or from freshly organic ligands leached from aerosol particles (Kersten et al., 1991), can affect the solubility. For example, complexation has also been observed for $\mathrm{Cu}$ (Maring and Duce, 1989), Fe (Zhuang et al., 1992) as well as some other metals (Maring and Duce, 1990) in seawater, that may alter the dissolution rate, equilibrium concentration, and then seawater solubility of aerosol metals. In summary, the solubility of all interested metals can reach maximal values within $1 \mathrm{~h}$, consistent with earlier studies (e.g. Kersten et al., 1991; Davison et al., 1994). Therefore 1-h exposure was selected for the leaching experiments on other samples in the following section.

\subsection{Comparing the seawater solubility of selected aerosol metals between two sites}

All data on seawater solubilities for aerosol metals from the two studied sites are given in Tables 2 (Hsiyu) and 3 (Santiaolun). The standard deviations listed in the two tables are comprehensive uncertainties that arose from sample handling, analysis and inhomogeneity, and propagation of errors through calculations. Results reveal that $\mathrm{Al}$ and $\mathrm{Fe}$ solubilities for the Hsiyu aerosols have low percentages falling within a narrow range from $<1 \%$ to near $7 \%(\mathrm{Al})$ and $6 \%(\mathrm{Fe})$ with averages of $1.3 \%(\mathrm{Al})$ and $1.1 \%(\mathrm{Fe})$. For Santiaolun, Al has a solubility range comparable with that of the Hsiyu aerosols, while $\mathrm{Fe}$ has a somewhat higher percentage as compared to Hsiyu, ranging from $1 \%$ to $10 \%$. With regard to trace metals, the seawater solubilities of $\mathrm{Mn}$, $\mathrm{Zn}, \mathrm{Cu}$ and $\mathrm{Ni}$ for the Hsiyu aerosols vary greatly by a factor of five or more: range $4-74 \%$ (average $43 \%$ ) for 
$\mathrm{Mn}, 1-77 \%$ (45\%) for $\mathrm{Zn}, 9-48 \%(26 \%)$ for $\mathrm{Cu}$, and $1-86 \%(50 \%)$ for $\mathrm{Ni}$. In contrast, relatively constant but higher percentages were found throughout in the Santiaolun aerosols: range 57-79\% (average 66\%) for $\mathrm{Mn}, 70-85 \%$ (81\%) for $\mathrm{Zn}, 29-54 \%$ (42\%) for $\mathrm{Cu}$, and $74-91 \%(83 \%)$ for Ni. Aerosols from Hsiyu and Santiaolun have contrasting $\mathrm{Cd}$ ranges of $20-91 \%$ and $88-91 \%$ with averages of $69 \%$ and $89 \%$, respectively.

Overall, both dust-derived elements $\mathrm{Al}$ and Fe have very low soluble proportions for the two sites (Table 4), attributable to their inert nature in that mineral dust particles predominantly bind within the stable form of crystalline aluminosilicate (Spokes et al., 1994; Bonnet and Guieu, 2004). Comparing the solubility patterns of $\mathrm{Mn}, \mathrm{Zn}, \mathrm{Cu}, \mathrm{Ni}, \mathrm{Pb}$ and $\mathrm{Cd}$ between the two sites, the seawater solubility of the Hsiyu aerosols is quite variable, but (slightly) low relative to that of the Santiaolun aerosols. The former were collected over a long period covering the less-polluted summer and polluted winter, whereas the latter was collected for a short period only in the relatively polluted winter. Fig. 3 illustrates the seasonal patterns of $\mathrm{EF}_{\text {crust }}$ and solubility of $\mathrm{Ni}$ and $\mathrm{Pb}$, sharing a common trend of low summertime but high wintertime values. Accordingly, this fact can explain why most Hsiyu samples with low solubilities are mainly summertime samples, usually characterized by less pollution, which can be elucidated by low $\mathrm{EF}_{\text {crust }}$ values (Table 2). On the other hand, relatively constant but large solubilities of the Santiaolun samples were observed for anthropogenic metals ( $\mathrm{Mn}, \mathrm{Zn}, \mathrm{Cu}, \mathrm{Ni}, \mathrm{Pb}$ and $\mathrm{Cd}$ ). For instance, metals in the Santiaolun samples were higher than those in the Hsiyu samples by a factor of 1.3 for Cd to 3.5 for Fe (Table 3 ). When considering the Hsiyu samples collected in winter alone, it shows higher solubility in the Santiaolun samples but lower solubility in the Hsiyu samples for all studied metals, although the differences become smaller as indicated by small $\mathrm{S} / \mathrm{H}_{\text {winter }}$ ratios in Table 3 . Similarly, a number of studies have compared the leachability of aerosol metals of anthropogenic and natural origins principally from urban and rural areas and suggested that chemical speciation is essentially responsible for the different dissolution patterns (Chester et al., 1993; Voutsa and Samara, 2002; Desboeufs et al., 2005). The phase associations may, however, transform into others during transport and the leachability thus changes. For instance, a portion of $\mathrm{Pb}$ in vehicle exhaust (also known as the dominant source of $\mathrm{Pb}$ in urban air), originally present in the form of halides which are more soluble, can react in the atmosphere to form oxides, which are very sparingly soluble (Maring and Duce, 1990). For further comparison, some literature data on solubilities of specific aerosol metals in a variety of solution mediums are compiled together with ours in Table 4. Overall, our results are generally in agreement with others (Kersten
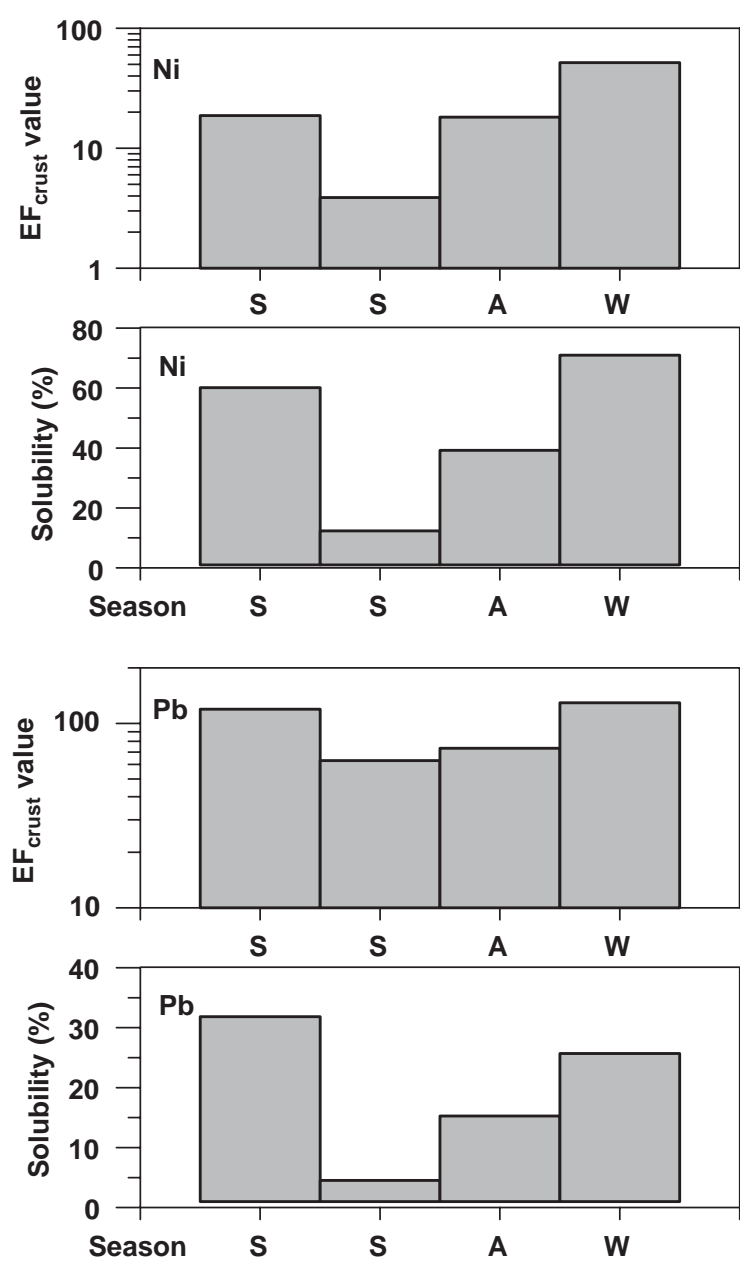

Fig. 3. Seasonality of $\mathrm{EF}_{\text {crust }}$ value and solubility for $\mathrm{Ni}$ (upper panel) and $\mathrm{Pb}$ (lower panel), revealing a typical pattern of low in summer and high in winter.

et al., 1991; Spokes et al., 1994; Lim et al., 1994; Guieu et al., 1994; Chester et al., 1997; Guerzoni et al., 1999b; Bonnet and Guieu, 2004). On the other hand, no systematic orders using similar/different leaching agents can be found among these studies, likely revealing that the solution matrix is not the first controlling factor of solubility rather than other factors such as solution $\mathrm{pH}$, speciation of specific metals in aerosol particles and the presence of organic, carbonaceous and acidic constituents (Chester et al., 1993; Voutsa and Samara, 2002; Desboeufs et al., 2005). The relative importance for these factors is inferred to be site-dependent.

\subsection{Controlling factors-EF $-E F_{\text {crust }}$ value and dust particle loading}

The magnitude of dissolvable fractions of specific aerosol metals can be related to several factors such as 
Table 3

Overall data $(n=8)$ on seawater solubility of various aerosol metals for all Santiaolun samples

\begin{tabular}{|c|c|c|c|c|c|c|c|c|}
\hline Sample ID & $\mathrm{Al}$ & $\mathrm{Fe}$ & $\mathrm{Mn}$ & $\mathrm{Zn}$ & $\mathrm{Ni}$ & $\mathrm{Cu}$ & $\mathrm{Pb}$ & $\mathrm{Cd}$ \\
\hline S911231 & $1.0 \pm 2.0\left(1^{\mathrm{a}}\right)$ & $2.0 \pm 2.1(0.9)$ & $57 \pm 1$ & $85 \pm 0(558)$ & $80 \pm 2(37)$ & $33 \pm 4(104)$ & $39 \pm 1(599)$ & $89 \pm 0(1823)$ \\
\hline S920106 & $2.0 \pm 4.5(1)$ & $2.9 \pm 3.9(0.9)$ & $69 \pm 1(3.1)$ & $80 \pm 1(295)$ & $86 \pm 2(91)$ & $29 \pm 5(74)$ & $43 \pm 2(490)$ & $90 \pm 1(1213)$ \\
\hline S920108 & $3.6 \pm 4.0$ & $2.4 \pm 2.3(1.1)$ & $71 \pm 1(2.9)$ & $84 \pm 0(196)$ & $87 \pm 1(77)$ & $39 \pm 3(32)$ & $39 \pm 1(302)$ & $91 \pm 0(673)$ \\
\hline S920114 & $0.4 \pm 1.1$ & $1.3 \pm 0.2(0.6)$ & $60 \pm 0(1.0)$ & $70 \pm 0$ & $74 \pm 2(6)$ & $50 \pm 2(4)$ & $33 \pm 0(65)$ & $89 \pm 0(85)$ \\
\hline S920118 & $0.4 \pm 1.5(1)$ & $1.4 \pm 1.2(0.7)$ & $57 \pm 1(1.4)$ & $75 \pm 0(50)$ & $81 \pm 2(13)$ & $54 \pm 2(10)$ & $29 \pm 1(133)$ & $89 \pm 1(326)$ \\
\hline S920120 & $3.2 \pm 6.2(1)$ & $7.9 \pm 3.5(1.2)$ & $79 \pm 1(3.4)$ & $85 \pm 1(340)$ & $91 \pm 1(112)$ & $42 \pm 4(98)$ & $43 \pm 2(563)$ & $91 \pm 1(1164)$ \\
\hline S920127 & $5.7 \pm 2.2$ & $10.0 \pm 1.3(0.8)$ & $71 \pm 0(2.3)$ & $84 \pm 0$ & $86 \pm 1(17)$ & $48 \pm 3(64)$ & $65 \pm 0(549)$ & $88 \pm 0(894)$ \\
\hline S920129 & $4.0 \pm 2.0$ & $5.3 \pm 1.3(0.8)$ & $66 \pm 0$ & $83 \pm 0(250)$ & $82 \pm 2(29)$ & $39 \pm 3(83)$ & $49 \pm 1(697)$ & $89 \pm 1(1330)$ \\
\hline \multicolumn{9}{|l|}{ Average } \\
\hline & $2.5 \pm 1.8$ & $4.2 \pm 1.6$ & $66 \pm 1$ & $81 \pm 1$ & $83 \pm 1$ & $42 \pm 2$ & $43 \pm 1$ & $90 \pm 1$ \\
\hline $\mathrm{S} / \mathrm{H}_{\mathrm{all}}^{\mathrm{b}}$ & 2.0 & 3.6 & 1.5 & 1.8 & 1.7 & 1.6 & 2.1 & 1.3 \\
\hline $\mathrm{S} / \mathrm{H}_{\text {winter }}{ }^{\mathrm{c}}$ & 1.1 & 1.7 & 1.04 & 1.3 & 1.1 & 1.2 & 1.5 & 1.2 \\
\hline
\end{tabular}

${ }^{\mathrm{a} N u m b e r s}$ in parentheses are crustal enrichment factors.

${ }^{\mathrm{b}} \mathrm{S} / \mathrm{H}_{\text {all }}$ is the ratio of average solubility of a metal in the Santiaolun aerosols to that in all Hsiyu aerosols.

${ }^{\mathrm{c}} \mathrm{S} / \mathrm{H}_{\text {winter }}$ is the ratio of average solubility of a metal in the Santiaolun aerosols to that in Hsiyu's wintertime aerosols.

$\mathrm{EF}$ value, particle loading, $\mathrm{pH}$ value of solution medium, and aerosol type (which components dominate the aerosol composition) (Maring and Duce, 1989, 1990; Chester et al., 1993, 1997, 2000; Giusti et al., 1993; Spokes and Jickells, 1996; Guerzoni et al., 1999b). For the Hsiyu aerosols, we examined the correlation between seawater solubility and $\mathrm{EF}_{\text {crust }}$. A significantly positive relationship was observed between solubility and $\log$ $\mathrm{EF}_{\text {crust }}$ value for $\mathrm{Ni}$ and $\mathrm{Pb}$, as illustrated in Fig. 4, while weak or no correlations were observed for other anthropogenic metals studied (not shown). To some extent, this can be interpreted to mean that aerosol samples with more anthropogenic contributions, as elucidated by high $\mathrm{EF}_{\text {crust }}$ values, are more soluble than those with more natural contributions, as elucidated by low $\mathrm{EF}_{\text {crust }}$ values, at least for $\mathrm{Ni}$ and $\mathrm{Pb}$. Nonetheless, it seems not to exhibit a simple relationship between solubility and $\mathrm{EF}_{\text {crsut }}$ value for specific metals, otherwise all studied metals would show this correlation. Alternatively, this may indicate that the $\mathrm{EF}_{\text {crust }}$ value is not the most critical controlling factor of leachability for most aerosol metals. Desboeufs et al. (2005) suggested that the released concentrations are not related to the total metal composition or the particle origin, but are directly associated with the type of liaisons whereby the metals are bound in the solid matrix. They further concluded that in polluted regions the dissolved concentrations of aerosol metals in atmospheric waters are mainly governed by the elemental carbon content. Chester et al. (1993) suggested that the variations in solubilities of $\mathrm{Cu}, \mathrm{Pb}, \mathrm{Zn}, \mathrm{Cd}$ and $\mathrm{Mn}$ are not directly related to the $\mathrm{EF}_{\text {crust }}$ value but speciation-mediated. For instance, $\mathrm{Mn}$ and $\mathrm{Fe}$ have close $\mathrm{EF}_{\text {crust }}$ values but their solubilities are different with Mn unambiguously higher than Fe. Spokes et al. (1994) ascribed this to different phase associations between the two metals. Nevertheless, there still seems to be other complicated factors like dust loading resulting in obscuring the solubility versus $\mathrm{EF}_{\text {crust }}$ value relationship. Moreover, this does not mean that the ranking of seawater solubility is identical to that of $\mathrm{EF}_{\text {crust }}$ values for these selected metals (Chester et al., 1993).

Along with $\mathrm{EF}_{\text {crust }}$ values, significantly inverse powerlaw (i.e. $\log -\log$ ) relationships were found between solubility and dust loading with a range of $15-473 \mathrm{mg}^{-1}$ for $\mathrm{Al}, \mathrm{Fe}, \mathrm{Zn}$ and $\mathrm{Pb}$ at a confidence level of $95 \%$ ( $p$ value $<0.05$ ) (Fig. 5), revealing that the solubility decreases with increasing dust loading. It should be noted that dust particle loading alone was taken into account while other components such as sea salt, carbonaceous, sulfate and nitrate particles were not considered. Guerzoni et al. (1999b) observed exponentially negative relationships between $\mathrm{Al}, \mathrm{Fe}$ and $\mathrm{Pb}$ with total aerosol particle loadings rather than a specific component loading. Our results are very similar to theirs. This likely demonstrates the presence of adsorption and/or re-precipitation processes (Chester et al., 1993; Guerzoni et al., 1999b) that can also be interpreted as the dissolution kinetics of particle-reactive elements like $\mathrm{Al}, \mathrm{Fe}$ and $\mathrm{Pb}$ as described above. Recently, Bonnet and Guieu (2004) found that the percentage of Fe seawater solubility decreases with introduced aerosol particle loading, following a power law, more consistent with our results. They further suggested that such a result facilitates model simulation with respect to the dissolution process. Moreover, the Hsiyu samples were simply separated into two groups, namely a high loading group with dust loading higher than $50 \mathrm{mg}$ per filter and 


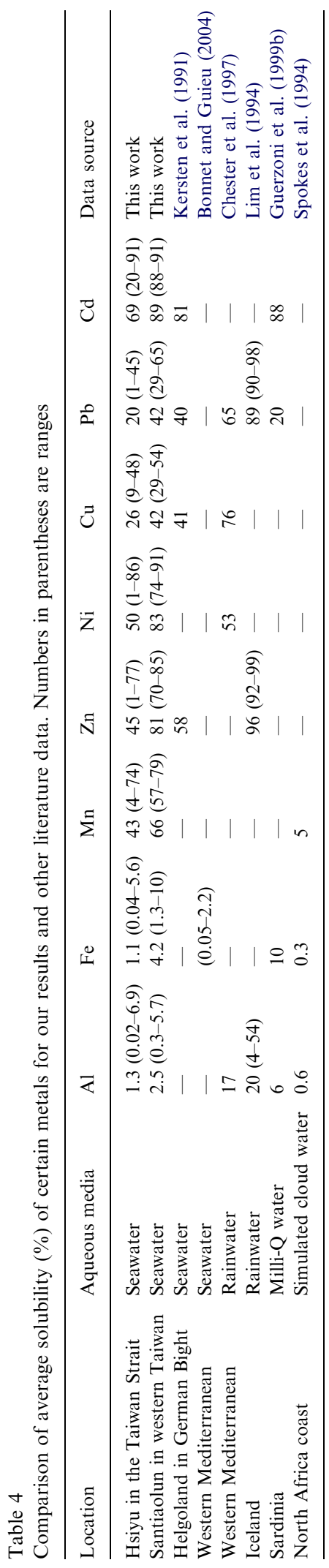

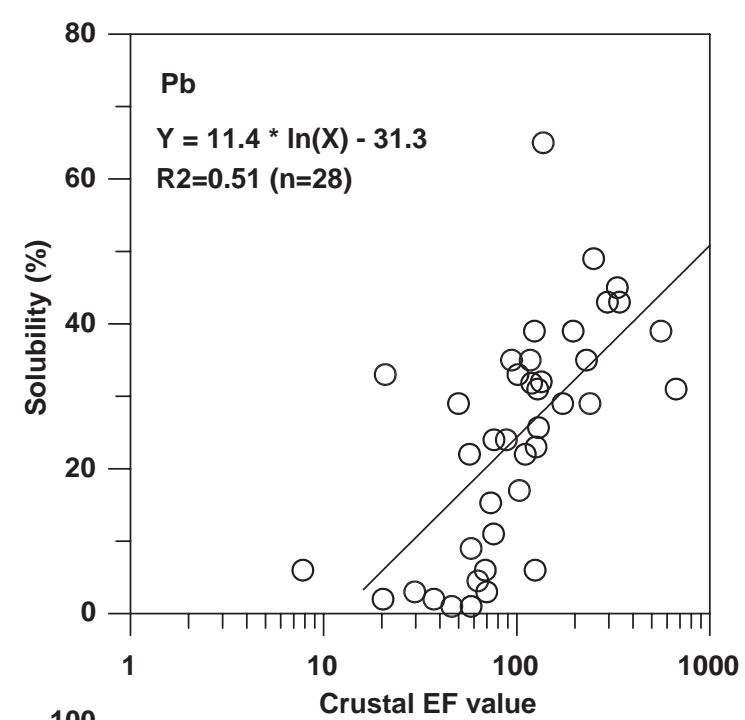

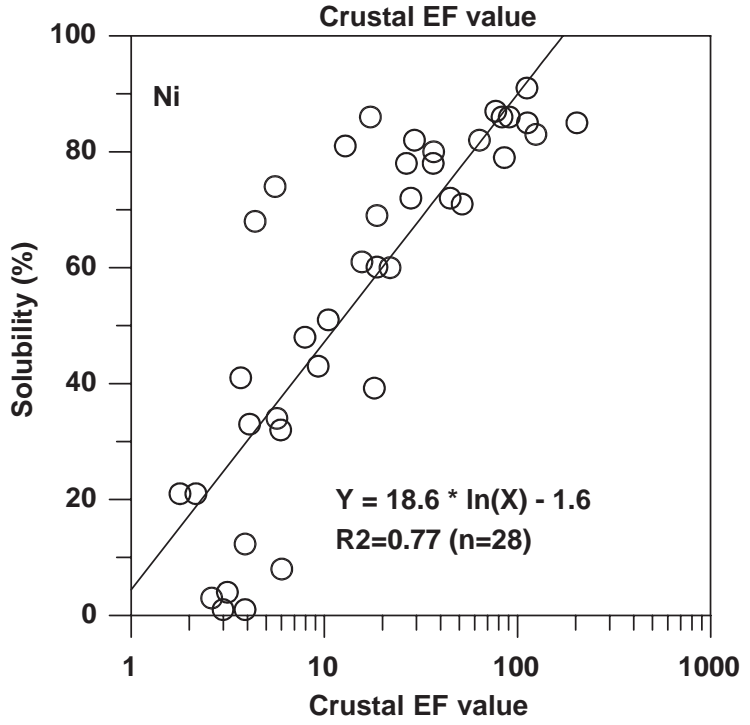

Fig. 4. Correlations of solubility versus $\log$ crustal EF value $\left(\mathrm{EF}_{\mathrm{Al}}\right)$ for $\mathrm{Pb}$ (upper panel), and $\mathrm{Ni}$ (lower panel) for the Hsiyu aerosols. Regression equations are also given.

a low loading group with dust loading lower than $50 \mathrm{mg}$ per filter. This $50 \mathrm{mg}$ per filter is a purely arbitrary value although it is close to the mean loading ( $43 \mathrm{mg}$ per filter). As a result, the solubilities of selected metals for low loading samples are approximately $20 \%$ (for $\mathrm{Cu}$ ) to over two fold (for $\mathrm{Al}$ ) higher than those for high loading samples (Table 2), again suggesting that during the dissolution the residual aerosol particles, especially those for dust, may change from a donator in the initial stage to a receptor/scavenger in a later stage for those dissolved metals (Chester et al., 1993; Bonnet and Guieu, 2004). Two physicochemical processes simultaneously occur when aerosol particles enter the seawater, namely the dissolution of $\mathrm{Fe}$ from aerosol particles and 

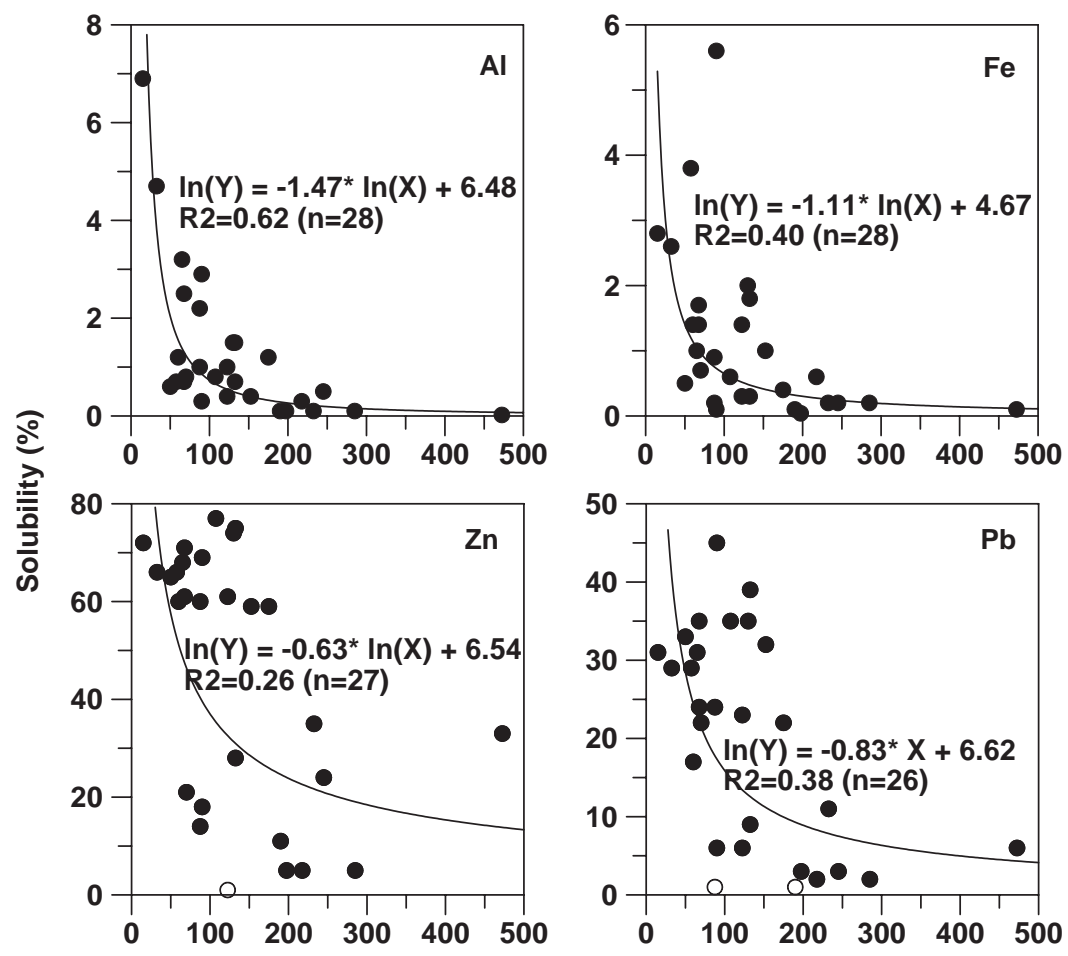

Dust loading (mg/l)

Fig. 5. Power-law correlations (i.e. $\log -\log$ ) of solubility versus dust loading for Al (upper left panel), Fe (upper right panel), $\mathrm{Zn}$ (lower left panel), and $\mathrm{Pb}$ (lower right panel) for the Hsiyu aerosols. Regression equations are also given. One (for $\mathrm{Zn}$ ) and two (for $\mathrm{Pb}$ ) outliers indicated by open circles were not included for regression.

adsorption of dissolved $\mathrm{Fe}$ onto the particle surface. This may imply that even pulse-like airborne dust depositions are rather important in stimulating marine productivity because of high dissolved Fe inputs while adsorption processes by abundant dust particles and/or background suspended particulates likely reduce the bioavailable amount of dissolved Fe.

\section{Conclusions}

The dissolution kinetics of aerosol metals $\mathrm{Al}, \mathrm{Fe} \mathrm{Mn}$, $\mathrm{Zn}, \mathrm{Cu}, \mathrm{Ni}, \mathrm{Pb}$ and $\mathrm{Cd}$ revealed that most soluble fractions could be released within $1 \mathrm{~h}$, while slight readsorption occurred for those particle-reactive metals such as $\mathrm{Al}, \mathrm{Fe}$ and $\mathrm{Pb}$. For the Hsiyu aerosols, the solubilities of selected metals were in the order: $\mathrm{Al}$ $(1.3 \%)=\mathrm{Fe} \quad(1.1 \%)<\mathrm{Pb} \quad(20 \%) \leqslant \mathrm{Cu} \quad(27 \%)<\mathrm{Mn}$ $(43 \%) \leqslant \mathrm{Zn} \quad(45 \%) \leqslant \mathrm{Ni} \quad(50 \%)<\mathrm{Cd} \quad(69 \%) . \quad$ This order is not identical with that of $\mathrm{EF}_{\text {crust }}$ values. The controlling factors of seawater solubility include $\mathrm{EF}_{\text {crust }}$ value, particle loading and aerosol characteristics. Log solubilities of $\mathrm{Pb}$ and $\mathrm{Ni}$ correlates with their individual $\mathrm{EF}_{\text {crust }}$ values, suggesting that more polluted aerosol particles can generally release more soluble constituents. Additionally, inverse power-law correlations observed between solubilities and dust loadings for $\mathrm{Al}, \mathrm{Fe}, \mathrm{Pb}$ and $\mathrm{Zn}$ imply that more abundant lithogenic particles in seawater lead to lower leachable fractions of aerosol metals as theses dust-rich aerosol particles appear to switch roles from contributor to scavenger. In summary, this study will facilitate to precisely quantify the input amounts of dissolvable aerosol metals into the sea through dry deposition and then to accurately assess the potential impacts on marine biogeochemistry.

\section{Acknowledgments}

We are grateful to two anonymous reviewers for their constructive comments. We thank Dr. C. N. Hsu and Mr. K. Huang for their help with aerosol sampling. Thanks are also extended to Prof. H. S. Yu and the technicians and crew of R/V Ocean Researcher I for help with seawater sampling. This work was supported by National Science Council (R.O.C.) grants NSC 80-0209M002A-18 and NSC 81-0209-M002A-17 to F. J. L. 


\section{References}

Avila, A., Rodrigo, A., 2004. Trace metal fluxes in bulk deposition, throughfall and stemflow at two evergreen oak stands in NE Spain subject to different exposure to the industrial environment. Atmospheric Environment 38, 171-180.

Barbeau, K., Moffett, J.W., 2000. Laboratory and field studies of colloidal iron oxide dissolution as mediated by phagotrophy and photolysis. Limnology and Oceanography 45, 827-835.

Bonnet, S., Guieu, C., 2004. Dissolution of atmospheric iron in seawater. Geophysical Research Letters 31, Art. No. L03303.

Bopp, L., Kohfeld, K.E., Le Quere, C., Aumont, O., 2003. Dust impact on marine biota and atmospheric $\mathrm{CO}_{2}$ during glacial periods. Paleoceanography 18, Art. No. 1046.

Boyd, P.W., et al., 2000. A mesoscale phytoplankton bloom in the polar Southern Ocean stimulated by iron fertilization. Nature 407, 695-702.

Bruland, K.W., Donat, J.R., Hutchins, D.A., 1991. Interactive influences of bioactive trace-metals on biological production in oceanic waters. Limnology and Oceanography 36, 1555-1577.

Butler, A., 1998. Acquisition and utilization of transition metal ions by marine organisms. Science 281, 207-210.

Chester, R., Murphy, K.J.T., Lin, F.J., Berry, A.S., Bradshaw, G.A., Corcoran, P.A., 1993. Factors controlling the solubilities of trace metals from non-remote aerosols deposited to the sea surface by the 'dry' deposition mode. Marine Chemistry 42, 107-126.

Chester, R., Bradshaw, G.F., Corcoran, P.A., 1994. Tracemetal chemistry of the North Sea particulate aerosolconcentrations, sources and sea-water fates. Atmospheric Environment 28, 2873-2883.

Chester, R., Nimmo, M., Corcoran, P.A., 1997. Rain water aerosol trace metal relationships at Cap Ferrat: a coastal site in the western Mediterranean. Marine Chemistry 58, 293-312.

Chester, R., Nimmo, M., Fones, G.R., Keyse, S., Zhang, J., 2000. The solubility of $\mathrm{Pb}$ in coastal marine rainwaters: $\mathrm{pH}-$ dependent relationships. Atmospheric Environment 34, 3875-3887.

Coale, K.H., 1991. Effects of iron, manganese, copper, and zinc enrichments on productivity and biomass in the Sub-Arctic Pacific. Limnology and Oceanography 36, 1851-1864.

Coale, K.H., et al., 1996. A massive phytoplankton bloom induced by an ecosystem-scale iron fertilization experiment in the equatorial Pacific Ocean. Nature 383, 495-501.

Cooper, D.J., Watson, A.J., Nightingale, P.D., 1996. Large decrease in ocean surface $\mathrm{CO}_{2}$ fugacity in response to in situ iron fertilization. Nature 383, 511-513.

Davison, W., Arewgoda, C.M., Hamilton-Taylor, J., Hewitt, C.N., 1994. Kinetics of dissolution of lead and zinc from rural atmospheric aerosols in fresh-water and synthetic solutions. Water Research 28, 1703-1709.

Desboeufs, K.V., Losno, R., Vimeux, F., Cholbi, S., 1999. The pH-dependent dissolution of wind-transported Saharan dust. Journal of Geophysical Research 104, 21287-21299.
Desboeufs, K.V., Losno, R., Colin, J.L., 2001. Factors influencing aerosol solubility during cloud processes. Atmospheric Environment 35, 3529-3537.

Desboeufs, K.V., Sofikitis, A., Losno, R., Colin, J.L., Ausset, P., 2005. Dissolution and solubility of trace metals from natural and anthropogenic aerosol particulate matter. Chemosphere 58, 195-203.

de Vries, W., Bakker, D.J., Groenenberg, J.E., Reinds, G.J., Bril, J., van Jaarsveld, J.A., 1998. Calculation and mapping of critical loads for heavy metals and persistent organic pollutants for Dutch forest soils. Journal of Hazardous Materials 61, 99-106.

Duce, A., et al., 1991. The atmospheric input of trace species to the world oceans. Global Biogeochemistry Cycles 5, 193-259.

Giusti, L., Yang, Y.L., Hewitt, C.N., Hamilton-Taylor, J., Davison, W., 1993. The solubility and partitioning of atmospherically derived trace metals in artificial and natural waters: a review. Atmospheric Environment 27A, 1567-1578.

Guerzoni, S., et al., 1999a. The role of atmospheric deposition in the biogeochemistry of the Mediterranean Sea. Progress in Oceanography 44, 147-190.

Guerzoni, S., Molinaroli, E., Rossini, P., Rampazzo, G., Quarantotto, G., de Falco, G., Cristini, S., 1999b. Role of desert aerosol in metal fluxes in the Mediterranean area. Chemosphere 39, 229-246.

Guieu, C., Duce, R., Arimoto, R., 1994. Dissolved input of manganese to the ocean-aerosol source. Journal of Geophysical Research 99, 18789-18800.

Hand, J.L., Mahowald, N.M., Chen, Y., Siefert, R.L., Luo, C., Subramaniam, A., Fung, I., 2004. Estimates of atmosphericprocessed soluble iron from observations and a global mineral aerosol model: biogeochemical implications. Journal of Geophysical Research 109 (D17) Art. No. D17205.

Hsu, S.C., Lin, F.J., Jeng, W.L., Chung, Y., Shaw, L.M., 2003a. Hydrothermal signatures in the southern Okinawa Trough detected by the sequential extraction of settling particles. Marine Chemistry 84, 49-66.

Hsu, S.C., Lin, F.J., Jeng, W.L., Tang, T.Y., 2003b. Spatial distributions of cadmium over a cyclonic eddy in the southern East China Sea. Journal of Marine Systems 39, 153-166.

Hsu, S.C., Liu, S.C., Lin, C.Y., Hsu, R.T., Huang, Y.T., Chen, Y.W., 2004. Metal compositions and characterizations of $\mathrm{PM}_{10}$ and $\mathrm{PM}_{2.5}$ aerosols in Taipei during the springtime, 2002. Terrestrial, Atmospheric and Oceanic Sciences 15, 925-948.

Hsu, S.C., Liu, S.C., Jeng, W.L., Lin, F.J., Huang, Y.T., Lung, S.C.C., Liu, T.H., Tu, J.Y., 2005. Variations of $\mathrm{Cd} / \mathrm{Pb}$ and $\mathrm{Zn} / \mathrm{Pb}$ ratios in Taipei aerosols reflecting long-range transport or local pollution emissions. Science of the Total Environment, in press.

Hutchins, D.A., Witter, A.E., Butler, A., Luther, G.W., 1999. Competition among marine phytoplankton for different chelated iron species. Nature 400, 858-861.

Jickells, T.D., 1999. The inputs of dust derived elements to the Sargasso Sea: a synthesis. Marine Chemistry 68, 5-14.

Kersten, M., Kriews, M., Forstner, U., 1991. Partitioning of trace metals released from polluted marine aerosols in coastal seawater. Marine Chemistry 36, 165-182. 
Kumar, N., Anderson, R.F., Mortlock, R.A., Froelich, P.N., Kubik, P., Dittrichhannen, B., Suter, M., 1995. Increased biological productivity and export production in the glacial Southern-Ocean. Nature 378, 675-680.

Lim, B., Jickells, T.D., Colin, J.L., Losno, R., 1994. Solubilities of $\mathrm{Al}, \mathrm{Pb}, \mathrm{Cu}$, and $\mathrm{Zn}$ in rain sampled in the marineenvironment over the North Atlantic Ocean and Mediterranean Sea. Global Biogeochemical Cycles 8, 349-362.

Lin, F.J., Hsu, S.C., Jeng, W.L., 2000. Lead in the southern East China Sea. Marine Environmental Research 49, 329-342.

Maring, H.B., Duce, R.A., 1989. The impacts of atmospheric aerosols on trace metal chemistry in open ocean surface seawater. 2 Copper. Journal of Geophysical Research 94, 1039-1045.

Maring, H.B., Duce, R.A., 1990. The impacts of atmospheric aerosols on trace metal chemistry in open ocean surface seawater. 3 Lead. Journal of Geophysical Research 95, 5341-5347.

Martin, J.H., Fitzwater, S.E., 1988. Iron deficiency limits phytoplankton growth in the North-East Pacific Subarctic. Nature 331, 341-343.

Martin, J.H., et al., 1994. Testing the iron hypothesis in ecosystems of the equatorial Pacific. Nature 371, 123-129.

Petit, J.R., et al., 1999. Climate and atmospheric history of the past 420,000 years from the Vostok ice core, Antarctica. Nature 399, 429-436.

Schulz, K.G., Zondervan, I., Gerringa, L.J.A., Timmermans, K.R., Veldhuis, M.J.W., Riebesell, U., 2004. Effect of trace metal availability on coccolithophorid calcification. Nature 430, 673-676.

Spokes, L.J., Jickells, T.D., 1996. Factors controlling the solubility of aerosol trace metals in the atmosphere and on mixing into seawater. Aquatic Geochemistry 1, 355-374.

Spokes, L.J., Jickells, T.D., Lim, B., 1994. Solubilization of aerosol trace-metals by cloud processing - a laboratory study. Geochimica et Cosmochimica Acta 58, 3281-3287.

Statham, P.J., Chester, R., 1988. Dissolution of manganese from atmospheric particulates into seawater and rainwater. Geochimica et Cosmochimica Acta 52, 2433-2437.
Sunda, W.G., Huntsman, S.A., 1998. Interactive effects of external manganese, the toxic metals copper and zinc, and light in controlling cellular manganese and growth in a coastal diatom. Limnology and Oceanography 43, 1467-1475.

Taylor, S.R., 1964. Abundance of chemical elements in the continental crust: a new table. Geochimica et Cosmochimica Acta 28, 1237-1285.

Van den Hout, K.D., et al., 1999. The impact of atmospheric deposition of non-acidifying substances on the quality of European forest soils and the North Sea. Water, Air and Soil Pollution 109, 357-396.

Voutsa, D., Samara, C., 2002. Labile and bioaccessible fractions of heavy metals in the airborne particulate matter from urban and industrial areas. Atmospheric Environment 36, 3583-3590.

Wise, M.E., Brooks, S.D., Garland, R.M., Cziczo, D.J., Martin, S.T., Tolbert, M.A., 2003. Solubility and freezing effects of $\mathrm{Fe}^{2+}$ and $\mathrm{Mg}^{2+}$ in $\mathrm{H}_{2} \mathrm{SO}_{4}$ solutions representative of upper tropospheric and lower stratospheric sulfate particles. Journal of Geophysical Research 108 Art. No. 4434.

Yuan, C.S., Sau, C.C., Chen, M.C., Huang, M.H., Chang, S.W., Lin, Y.C., Lee, C.G., 2004. Mass concentration and size-resolved chemical composition of atmospheric aerosols sampled at the Pencadores Islands during Asian dust storm periods in the years of 2001 and 2002. Terrestrial, Atmospheric and Oceanic Sciences 15, 857-879.

Zhu, X., Prospero, J.M., Savoie, D.L., Millero, F.J., Zika, R.G., Saltzman, E.S., 1993. Photoreduction of iron (III) in marine mineral aerosol solutions. Journal of Geophysical Research 98, 9039-9046.

Zhuang, G.S., Yi, Z., Duce, R.A., Brown, P.R., 1992. Chemistry of iron in marine aerosols. Global Biogeochemistry Cycles 6, 161-173.

Zuo, Y., 1995. Kinetics of photochemical/chemical cycling of iron coupled with organic substances in cloud and fog droplets. Geochimica et Cosmochimica Acta 59, 3123-3130. 